\title{
DR. GULYÁS LÁSZLÓ: KÉT RÉGIÓ - FELVIDÉK ÉS VAJDASÁG - SORSA AZ OSZTRÁK-MAGYAR MONARCHIÁTÓL NAPJAINKIG
}

\author{
(Hazai Térségfejlesztö Rt., Hn., 2005, 233 o.)

\section{BALI LÓRÁNT}

Az 1990-es évek elejétöl fogva a magyar földrajztudomány egyre nagyobb teret szentel a Kárpát-medence térszerkezetét vizsgáló regionális kutatásoknak. Az államszocializmus időszakában megszakadt, felhagyott kutatási irányok éledtek fel újból. Ilyen ez a könyv is, mely a szerző doktori értekezésének bővített változata, és a Pécsi Tudományegyetem Közgazdaságtudományi Kar „Regionális Politika és Gazdaságtan" PhD programjának keretében készült.

A könyv hét jól elkülöníthetô, de egymásra épuilő fejezetre tagolódik. Bemutatja a Monarchia létrejöttét, és magyarázza a több, mint „,50 éves” házasság problémáit, tisztázva a címben is szereplő ,régiơ” fogalmát. Jó metodikával haladva, a következő részben a széttagolódáshoz vezető utolsó lépcsöket bemutatva (felmerülö határ koncepciók, hadicélok) eljut a „Trianoni határok” kialakulásához.

A következőkben széleskörü kitekintést nyújt a két állam két világháború közti térszerkezeti és gazdasági viszonyairól, illetve a feszítő nemzetiségi problémákról. Ezek miatt a mesterséges, koherenciával nem rendelkezö országok könnyủ prédáivá váltak a német imperialisztikus törekvéseknek. E törekvések államrendezö terveiről is olykor kuriózumnak számító leírások és térképek kerülnek a szemünk elé, gondoljunk a Prinz Eugen Gau nevü tervezett német „blokk” államra.

A szocialista éra csaknem ötvenéves korszakáról Gulyás László így szól: „Leginkább egy kerékhez hasonlítható, amelynek közepe Moszkva, melyet küllők kötnek össze az egyes országokkal, de a küllök közt nincs kapcsolat." E mondattal teljesen megvilágítja azt a felülről épülő zsákutcás „fejlődést”, amely a Felvidéket Szlovákia peremrégiójává, a Vajdaságot pedig Jugoszlávia, majd Szerbia egyik beteg részévé tette.

A 6. fejezetben elénk tárul egy, a térségben megkésett, de később annál gyorsabb fejlödésủ Szlovákia, ezen belül a Felvidék, a maga államszervezési problémáinak tömkelegével (Csehországhoz való viszony 1992-ig, illetve az etnikai befolyásoltságtól sem mentes közigazgatási térszervezés, a Kárpátok Eurorégióhoz való csatlakozás problémás létrejötte).

Az értekezés 51 ábrájával és 28 térképével szemléletessé és könnyen érthetöbbé, áttekinthetővé teszi a lejátszódott folyamatokat. Hasznos lett volna az ábrákat és a térképeket a könyv végébe, egy csokorba gyüjteni. A mü tankönyv jellegénél fogva ez könnyebbé és egyszerübbé tenné az oktatási célokra való felhasználást.

Gulyás László „,terjedelmes publikációs munkássággal” készült a könyv megírására, széleskörủ szakirodalomra támaszkodva. A könyv hiánypótló. Annak ellenére, hogy a 
magyar történelemtudomány, történeti földrajz, politikai földrajz több szempontból is vizsgálta az Osztrák-Magyar Monarchia felbomlásának és az utódállamokban maradt magyar nemzetiség problémáját, átfogó társadalmi-gazdasági elemezés nemzetietnikai vizsgálattal vegyítve 1867-től napjainkig terjedő időszakra nem született.

A két régió kiválasztása és közös elemzése inkább aktuális, mint szerencsés. A Felvidék Szlovákia részeként hazánkkal együtt integrálódott az Európai Unióba, míg a Vajdaság Szerbia és Montenegró révén vagy nem fog, vagy felkészületlenül, éretlenül csatlakozik. Amíg a Felvidékkel kapcsolataink normalizálódtak és fejlödési pályára álttak, addig a Vajdaság a rendszerváltás utáni magyar külpolitika egyik permanens problémája még ma is. Annak ellenére, hogy a két régió mindvégig a Magyar Királyság része volt, az 1000 év alatt teljesen ellentétes pályát futottak be. A Felvidék a magyar ipar egyik bölcsöje volt, a Vajdaságban a mezőgazdaság dominált. Az elöbbi döntően két nemzetiségü a könyv által vizsgált időszakban (szlovák, magyar), az utóbbi három nemzetiségủ (szerb, magyar, német) és vegyes eloszlású. Szerencsésebb lett volna talán a fent felvázoltak alapján a Felvidék helyett Erdélyt választani.

Az élvezhetőséget negatívan befolyásolja a lábjegyzeteknek a könyv hátuljában való összegyüjtése, szerencsésebb lett volna a lap aljára tenni öket. Az irodalomjegyzék a témában munkálkodó kutató és a témakörben diploma dolgozó egyetemista számára egyaránt jelentős segítséget fog nyújtani.

A Kárpát-medence perem-régióinak kutatása a 21. sz. egyik legfontosabb témája kell, hogy legyen. Cholnoky Jenő gondolatait felidézve: ,a legtökéletesebb határok a hegységek".

Anélkül, hogy a földrajzi determinizmus hibájába esnénk, meg kell állapítanunk, hogy a Kárpátok koszorúja által körbe ölelt medence terület egy egész, amelyet a mesterségesen létrehozott államhatárok csak politikailag tudnak elválasztani egymástól. E területek - nyitott határok esetén - mindig is kapcsolódtak és kapcsolódni fognak társadalmi-gazdasági szempontból a magterülethez. Véleményem szerint ez az, ami a mủ aktualitását és fontosságát adja. 